\title{
Service Quality and Student Satisfaction Using ServQual Model: A Study of a Private Medical College in Saudi Arabia
}

\author{
Mohamad Tarif Sibai ${ }^{1}$, Bernardo Bay Jr. ${ }^{1}$ \& Rhodora dela Rosa ${ }^{2}$ \\ ${ }^{1}$ Quality and Accreditation Center, Mohammed Al-Mana College for Medical Sciences, Dammam, Saudi Arabia \\ ${ }^{2}$ Graduate School, Central Luzon State University, Nueva Ecija, Philippines \\ Correspondence: Mohamad Tarif Sibai, Quality and Accreditation Center, Mohammed Al-Mana College for \\ Medical Sciences, Abdulrazaq Bin Hammam Street, Al Safa, Dammam 34222, Saudi Arabia. E-mail: \\ MohammedA24@machs.edu.sa
}

Received: February 19, 2021

Accepted: March 24, 2021

Online Published: May 14, 2021

doi:10.5539/ies.v14n6p51

URL: https://doi.org/10.5539/ies.v14n6p51

\begin{abstract}
The study assessed the service quality and satisfaction among Pharmacy students at one of the private medical colleges in Saudi Arabia using ServQual model. Specifically, it sought to determine the respondents' profile in terms of gender, year level, and grade point average; service quality using SERVQUAL Model; over-all students' satisfaction of students on the provided college services; and which profile and service quality dimensions best predict the over-all satisfaction of the students. Using a descriptive statistics and Multiple Regression Analysis for data analysis, this paper had 189 respondents. Based on the results, majority of the respondents were female from levels 2, 3, and 4 with above average GPA. Responsiveness, empathy and tangibility dimensions of service quality had a negative gap, which means that the expected services did not meet the perceived services on the cited service quality dimensions. Meanwhile, when overall satisfaction was measured, students expressed satisfaction to the college services. Year level was a predictor for all measures of student satisfaction; while GPA was identified as a negative predictor to student satisfaction in terms of faculty. Students' satisfaction in terms of faculty was best predicted by responsiveness, assurance, tangibility. Meanwhile, assurance was a predictor of students' satisfaction in terms of curriculum. Responsibility, responsiveness and assurance, on the other hand were predictors of students' satisfaction in terms of students services and facilities. Finally, the overall student satisfaction was predicted by responsiveness, assurance and tangibility.
\end{abstract}

Keywords: assurance, curriculum, quality, satisfaction, ServQual

\section{Introduction}

Service quality research has tremendously gained its prominence among various industries like marketing, healthcare, public entities and other business operations. Undoubtedly, it has drawn large scale of attention to academic institutions which are aimed at refining educational services, policies and procedures.

The definition of service quality can be provided from the perspective of how the consumers or users of the service judge the service based on what they may have experienced (Onditi \& Wechuli, 2017). Therefore, delineating this idea originates from customers since quality is intended for consumers, that service quality is achieved when customers are satisfied or had exceeded their expectations (Grubor et al., 2009). This theory is supported by various studies on the significant relationship between the perceived service quality variables and overall satisfaction of service customers (Shpetim, 2012; Van Truong et al., 2016; Jhandir, 2012; Qadeer, 2014). Moreover, Sureshchandar et al. (2002) emphasized the direct relationship between these two concepts arguing that the likelihood of increasing customer satisfaction out of improving service quality is an impulsive effect. Zareim et al. (2015) went on highlighting that, "when service quality is studied as a multidimensional construct, it provides invaluable tips for managers and decision-makers as well". He argued that service quality is a multidimensional construct which leads managers identify efficient areas of service quality to ascertain customer satisfaction.

In an effort to gauge the effectiveness of an organization's service quality initiatives, customers' perceptions are gathered and measured. This measurement provides the information necessary for effective decision making, monitoring performance, and effectively allocating resources to enhance profitability (Kelso, 2008).

In higher education sector, service quality is considered as a key determinant of its performance. The existing 
literature on the service quality construct in higher education identifies many dimensions such as competence of staff, reputation of the institution, delivery styles by tutors and lecturers, reliability, tangibles, responsiveness, sufficiency of resources, administrative services, and attitude support services among others (Onditi \& Wechuli, 2017). Also, service quality is indicated as an essence for establishing and sustaining favorable relationship with customers and therefore it can be considered as an antecedent to satisfaction. In that sense, there is an existence of positive relationship between perceived service quality and student's satisfaction (Mestrovic, 2017).

According to Prakash and Muhammed (2016), it is evident that service quality plays a key role in predicting student satisfaction and subsequently in shaping their behavioral intentions. Bhuian (2016) noted that higher education has become an intensely competitive market where students look for evidences of service quality while making the uncertain and highly risky decision of choosing a university. Alves and Raposo (2010) reiterated that service quality in the field of education and higher learning particularly is not only essential and important, but it is also an important parameter of educational excellence. It has been found that positive perceptions of service quality has a significant influence on student satisfaction and thus satisfied student would attract more students through word-of-mouth communications.

Meanwhile, students' satisfaction can be defined as a short-term attitude resulting from an evaluation of students' educational experience, services and facilities (Weerasinghee \& Fernando, 2017). Since the students spend an important part of their life in the institute's campus, the quality of life of students in campus becomes an important factor in determining perceived service quality of the institute. Support facilities, social activities and interpersonal relationships are important dimensions to determine quality of life (Jain, Sinha \& De, 2010).

Students' satisfaction can be predicted according to Maimunah, Kaka and Finch by three factors, namely performance of trainers, services delivery, and support facilities, what is in accordance with Hill Lomas and MacGregor, who found in research on students' service quality experience that the lecturers and the support system are the most significant predictors of students' satisfaction. In conclusion, as primary customers, students' satisfaction determined by both academic and non-academic aspects, is crucial to the survival of any higher education institution (Mestrovic, 2017).

Servqual scale, which was developed in 1988 by Parasuraman et al. has been proven an efficient tool for assessing the perceptions and expectations among users with regard to service quality (Marshall \& Murdoch as cited by Pena et al., 2013). It is a worldwide recognized and used instrument for measuring service quality. Many researchers have studied and used this instrument for measuring service gaps in various service sectors (Nadi et al., 2016; Al-Momani, 2015).

SERVQUAL is a multiple item scale for measuring the five dimensions of service quality developed by Parasuraman et al. (2002) with the following five dimensions: Tangibles-Physical facilities, equipment and appearance of personnel; Reliability- Ability to perform the promised service dependably and accurately; Responsiveness-Willingness to help customers and provide prompt service; Assurance-Knowledge and courtesy of employees and their ability to inspire trust and confidence; Empathy-Caring, individualized attention the firm provides its customers.

It is deemed essential to determine what are the students' expectations and perceptions towards the services provided by the College employees, the delivery of instruction, the adequacy and availability of physical facilities, the relevance of the curriculum and various student services. The satisfaction of the students on these educational services needs to be assessed periodically to seek input from the students for continuous improvement. With that being mentioned, this study was conducted to determine the students' satisfaction level by identifying its service quality. Specifically, this study sought to: (1) describe the profile of the respondents according to sex, year level in the program, and their Grade Point Average; (2) identify the gaps between the level of students' perception and expectation on the provided by college services using SERVQUAL Model; (3) determine the level of overall satisfaction of students on the provided college services; and (4) identify which profile and dimensions of service quality best predict the overall satisfaction of the students.

\section{Method}

\subsection{Research Design, Site and Participants}

The descriptive-correlational design was used in this study. This research specifically described the student respondents in terms of their gender, year level in the program, and their grade point average. The study looked into their perception on the service quality being provided by the institution, their level of satisfaction; and which profile and dimensions of the service quality of the school best predict the students' level of satisfaction. 
This study was conducted during the first semester of the SY 2018-2019 at one of the private medical colleges, Program of Pharmacy in Dammam Saudi Arabia with a total of 189 participants using stratified random sampling method.

\subsection{Instrumentation}

This study utilized a modified SERVQUAL instrument in assessing service quality. Although the study used the structured instrument from the study of Donlagic and Fazlic (2015), some parts were changed to align with the current set-up in the college. Due to some modifications to the instrument, a reliability and validity test were conducted using Cronbach's Alpha test. The result of the test showed excellent remarks on the expectation and perception as well as curriculum and student services as denoted by the Cronbach alpha values which are greater than 0.90 while the area of faculty obtained good result with less than 0.9 and greater than 0.8 . This signifies that the set of instrument has good to excellent internal consistency and reliability for use.

\subsection{Data Collection and Analysis}

Upon approval of the proposal, the researcher personally distributed the survey questionnaires to 189 respondents across the college and was retrieved for tabulation, interpretation and analysis and discussion. With $100 \%$ retrieval rate, the questionnaires were tallied, interpreted, analyzed and discussed. The data gathered were analyzed by using the following statistical tools: frequency count and percentages to determine the number of responses and its percentages in terms of gender, year level in the program, and grade point average; weighted mean to describe the perception on service quality and the level of satisfaction of the students on the provided services of the college. The Multiple Hierarchical Regression Analysis was used to determine which of the five dimensions of service quality and their profiles best predict or determine student satisfaction rating. The data were interpreted and analyzed using SPSS Version 21 to identify dimensions of service quality that predict the overall satisfaction among the following services: faculty and instruction, curriculum, and student services and facilities.

\section{Results}

Theme One: Profile of the Respondents

Table 1. Profile of the respondents

\begin{tabular}{cccc}
\hline \multirow{2}{*}{ Demographic Profile } & F & $\%$ \\
& Male & 48 & 0.25 \\
Gender & Female & 141 & 0.75 \\
\hline \multirow{4}{*}{ Program Level } & Year 1 & 12 & 0.6 \\
& Year 2 & 48 & 0.26 \\
& Year 3 & 46 & 0.24 \\
& Year 4 & 45 & 0.24 \\
& Year 5 & 25 & 0.13 \\
& Year 6 & 13 & 0.70 \\
\hline \multirow{5}{*}{ Grade Point Average } & A+ (Exceptional) & 0 & 0 \\
& A (Excellent) & 14 & 0.8 \\
& B + (Superior) & 22 & 0.12 \\
& B (Very Good) & 29 & 0.15 \\
& C (Above Average) & 86 & 0.46 \\
& D+ (High Pass) & 12 & 0.6 \\
& D (Pass) & 14 & 0.6 \\
& &
\end{tabular}

The data show that Female respondents outnumbered the Male respondents. Majority of the respondents were from second, third, and fourth year levels. In terms of GPA, majority of the students have above average GPA.

Theme Two: Students' Perception on the Service Quality 
Table 2. Level of students' perception on the service quality provided by college services

\begin{tabular}{ccccccc}
\hline \multirow{2}{*}{ Reliability } & & Mean & SD & Mean Differences & t-value & p-value \\
& Perceived & 5.02 & 1.01 & -0.074 & 1.142 & 0.255 \\
& Expected & 5.10 & 1.13 & & & \\
Responsiveness & Perceived & 4.79 & 1.21 & -0.559 & 5.476 & 0.000 \\
& Expected & 5.35 & 1.01 & & & \\
Assurance & Perceived & 5.02 & 1.04 & & & \\
& Expected & 4.98 & 1.20 & 0.037 & 0.562 & 0.575 \\
& Perceived & 4.88 & 0.98 & & & \\
\multirow{5}{*}{ Tangibility } & Expected & 5.08 & 1.15 & -0.205 & 2.800 & 0.006 \\
& Perceived & 4.65 & 1.02 & & & \\
& Expected & 4.95 & 1.25 & -0.298 & 3.482 & 0.001 \\
\hline
\end{tabular}

Legend: Significant at $\mathrm{p}$-value $<0.05$.

It can be deduced that there is a gap result between the perceived and expected services for responsiveness, empathy and tangibility. The table shows that the significance value of responsiveness $(0.000)$, empathy $(0.006)$ and tangibility (0.001) are less than 0.05 at $95 \%$ level of significance, thus the null hypothesis is rejected under these variables.

Theme Three: Over-all Satisfaction of Students on the Provided College Services

Table 3. Level of over-all satisfaction of students on the provided college services

\begin{tabular}{ccc}
\hline Indicators & Mean & Verbal Interpretation \\
\hline Faculty & 4.34 & Satisfied \\
Curriculum & 4.16 & Satisfied \\
Student Services and Facilities & 3.92 & Satisfied \\
Composite Mean & 4.14 & Satisfied \\
\hline
\end{tabular}

Table 3 shows the level of satisfaction of the students on the provided college services. The data reveals that all services in terms of faculty (4.34), curriculum (4.16) and students services and facilities (3.92) are rated satisfied. Among the domains that had been investigated, faculty obtained the highest level of satisfaction, followed by the curriculum. However, students' services and facilities obtained the lowest weighted mean.

Theme 4: Hierarchical Regression predicting Students Satisfaction on the Provided College Services as to Over-all Satisfaction

Table 4. Hierarchical regression predicting students satisfaction on the provided college services as to over-all satisfaction

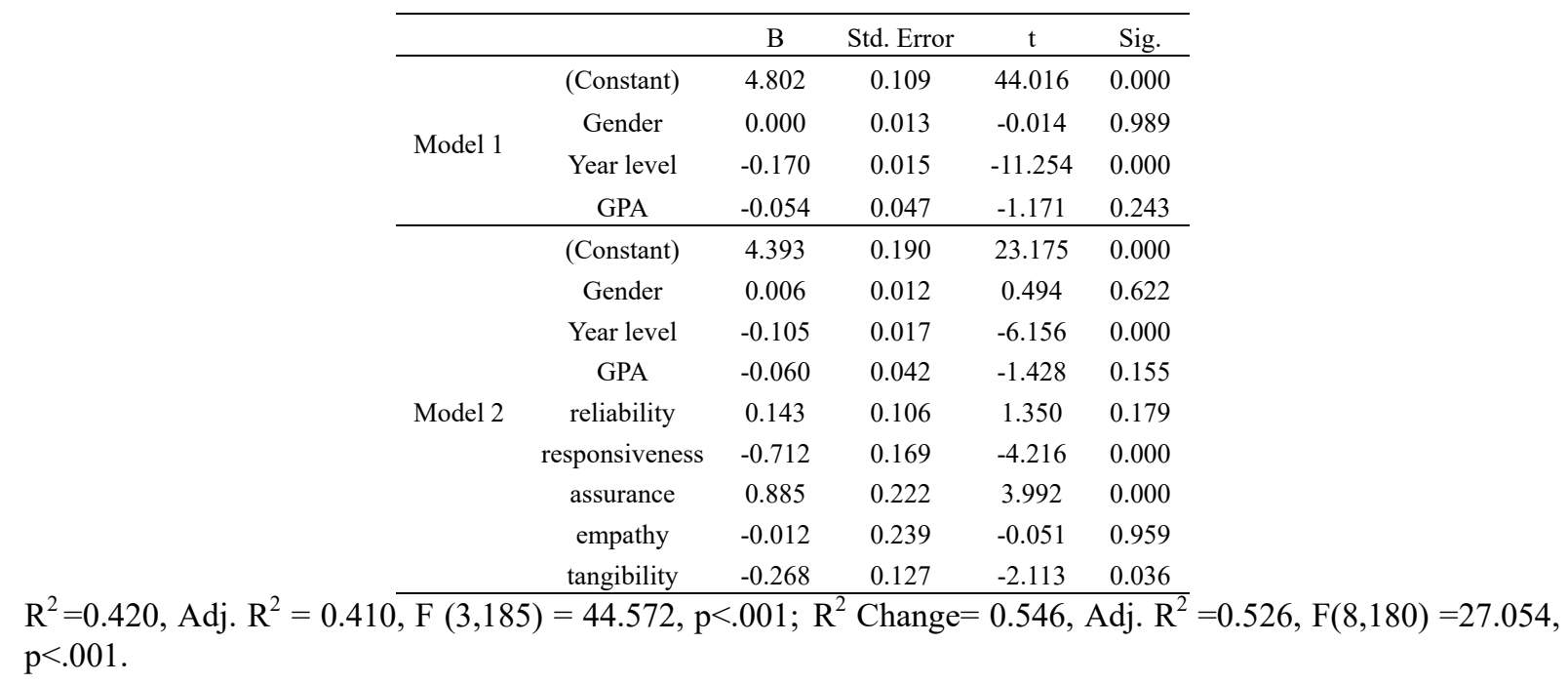


Based on the result, Model 1 shows significant effect of profile variable to student services, $R^{2}=0.420, \operatorname{Adj} . R^{2}$ $=0.410, F(3,185)=44.572, p<.001$. Year Level is a negative predictor of Satisfaction (student services), $\beta=-0.170$, Std .error $=0.015, t=-11.254, p<.001$. Furthermore, result of the hierarchical regression showed that the Model 2 also is significant, $R^{2}$ Change $=0.546$, Adjusted $R^{2}=0.526, F_{(8,180)}=27.054, p<.001$. Assurance is a positive predictor of over-all satisfaction where $\beta=0.885$, Std .error $=0.222, t=3.992, p<.001$, indicating that the better the assessment on the quality of services as to assurance, the more that the students are satisfied on the services provided in general, even when controlling for the effects of year level, responsiveness and tangibility. Conversely, year level, responsiveness and tangibility were considered negative predictors of over-all satisfaction, $\beta=-0.105$; $-0.172 ;-0.268$, Std .error $=0.017 ; 0.169 ; 0.127, t=-6.156 ;-4.126 ;-2.113, p<.001$ indicating that it is significant.

\section{Discussion}

\subsection{Profile of the Respondents}

For years, Saudi Arabia has been engulfed by a widespread gender gap, discrimination and inequality; however, the new era has ushered a paradigm shift that has beckoned a rising on women's empowerment process (Varshney, 2019) as evident in the current study. According to Janzen, Fitzpatrick and Suveges (2013), women have historically been attracted to pharmacy because it is widely perceived as a profession that offers them an opportunity to combine a professional career with a family.

In terms of year level, it is understandably perceived that as year progresses, the enrollment rate also drops. The yearly progression rate has been decreasing due to the various reasons like financial capabilities of the students, failure to pass the courses, failure due to absenteeism and dropout due to personal reasons. However, it is distressing to note in the data that, there were only 12 or $6 \%$ among all entire population comprising level 1 students. The reason behind a drop of enrollment for incoming Pharmacy students could be due to the introduction of some programs in the college including the Respiratory Care and Physical Therapy.

Meanwhile, Dorta-Guerra et al. (2019) noted that the grade point average is used to measure academic performance. It brings certain level of experience among students in acquiring knowledge and learning different skills from the college that might consider important dimension of their satisfaction.

\subsection{Students' Perception on the Service Quality Provided by College Services}

With the overall findings on students' perception where there is a gap between the perception and expectation of students in the college services' responsiveness, empathy, and tangibility, the study is expected to provide a very strong baseline data that would affect possible program modification or program enhancement. As stated by Gronroos (1984), understanding the service quality of the college will lead to evaluation process, hence assessing the achievement of services and its quality intended to be delivered and be obtained by consumers is necessary.

Recognizing the yielded results, the administration is now on the task of prioritizing the improvement of college services in terms of the quality dimensions which had notable gaps in terms of customers' expectation and perception. On the aspect of responsiveness, the faculty members must enhance their willingness to help in terms of providing extra help to their students. Also a noted negative gap on the way they respond timely and promptly towards the students' complaints and concerns should be addressed by the management. Meanwhile, with the students' perception on the level of empathy, the management should prioritize looking into how faculty members should demonstrate special attention in resolving specific concerns of the students because as the study of Son et al. (2018) revealed, empathy has positive effect on students' satisfaction on education services.

It is imperative for the management to ensure that their faculty members give attention when getting feedback from their students. This is to ensure that an open door policy is maintained and observed at all times that contribute to enhancing students' satisfaction level. On the other hand, with the negative gap observed in this study in terms of tangibility, the college must ensure that facilities and infrastructures specifically the parking provisions and signage must be improved. These facilities according to the study were revealed to be the weakest areas in terms of tangible aspect of the service quality dimension.

Although addressing these concerns need resources including manpower, finance and time; the management could see potential benefits by enhancing stakeholders' satisfaction. This could also pose probable decrease of student attrition and may attract more students to enhance the enrollment rate in the college. Selvi and Ponniah (2017) noted that service and quality are driving forces in the Pharmaceutical student's satisfaction. As Pharmaceutical student's satisfaction tussle for competitive advantage and high service quality, the evaluation of educational service quality is essential to provide motivation for and to give feedback on the effectiveness of educational plans and implementation. 


\subsection{Over-All Satisfaction of Students on the Provided College Services}

Surprisingly, results on over-all satisfaction do not coincide with their perceived service quality which all of the domains obtained negative gap. This interesting finding is invaluable information for academic leaders to think progressively that students are expecting something else beyond service quality. It means improvement of service quality will not necessarily increase the student satisfaction. The services provided by the Faculty members are considered the core of educational services which is quality instruction. It is good to note that the finding of this study provides insight that the students are satisfied primarily on the faculty. Several studies also suggest positive feedback of the students towards academic staff on how they delivered quality instruction which is culturally responsive and relevant to the needs of the industry (Long, 2018). Today's students are entering higher studies platform with new and diverse attitudes and talents as a result of social and cultural changes. These changes modify students' expectation levels and their subsequent satisfaction with the educational environment (Osman \& Saputra, 2019).

\subsection{Predicting Students Satisfaction on the Provided College Services as to Over-All Satisfaction}

Results showed that the higher the year level, the lesser satisfied on over-all satisafction on the services provided. Upon analyzing the result, it was found out that year level 3 students (4.32) are more satisfied compared to other year levels. This means that as students' progress, their expectations and perceptions and also their subsequent level of satisfaction depend on the college services provided. Hence, a strategic planning to improve the quality of college services is an imperative strategy to sustain high student satisfaction. This outcome provides support to previous study of Oluwunmi, Emeghe, and Ajayi (2016). The authors suggested that year level is not a predictor of students' satisfaction. Although there is little support or evidence, according to Grayson (2008), satisfaction likely is most directly a result of certain personality characteristics rather than year level that predispose students to evaluate their experiences in a positive manner.

With more validation and future investigations to prove, this study revealed that assurance (Hamza, 2009) is a predictor of students' satisfaction. This indicates that the respondents' satisfaction is dependent on the abilities of the employees of providing the promised college services dependably and accurately when service quality dimensions are taken into consideration. Moreover, it is important to note that whatever has been done to increase assurance in service quality has been widely accepted to increase student satisfaction. On the other way around, neglecting it may compromise the level of students' satisfaction.

The negative coefficient indicates that the higher the year level, responsiveness and tangibility, the lesser satisfaction on the over-all satisfaction to the services provided. With regard to year level, students from year level 3 are more satisfied with mean value of 4.32. This interesting finding is invaluable information for academic leaders to think progressively that students are expecting something else beyond service quality. It means improvement of service quality will not necessarily increase the student satisfaction. Today's students are entering higher studies platform with new and diverse attitudes and talents as a result of social and cultural changes. These changes modify students' expectation levels and their subsequent satisfaction with the educational environment (Osman \& Saputra, 2019). Saleem et al. (2017) also noted that service quality is imperative for higher education institutes where ensuring students' satisfaction with the school service is necessary in order to remain competitive and growing.

\section{Conclusions and Recommendations}

Based on the findings, the following conclusions were drawn: (1) majority of the respondents were female from levels 2, 3, and 4 with above average GPA; (2) responsiveness, empathy and tangibility are dimensions of service quality with negative gaps, which means that the expected services on these dimensions did not meet the perceived services provided by the college using ServQual model; (3) when over-all satisfaction was measured, students are satisfied with the college services in terms of faculty, curriculum and student services and facilities; and (4) using two models of hierarchical regression, only year level is the predictor (negative) to student satisfaction except for GPA which was identified as a negative predictor to student satisfaction in terms of faculty. In terms of service quality dimensions, this study found that only assurance is a positive predictor of students' satisfaction with the exception of reliability as a positive predictor for student services. Meanwhile, among all dimensions, responsiveness is a negative predictor to student satisfaction in terms of faculty, student services and over-all satisfaction. However, tangibility was also recorded as a negative predictor but affecting the faculty component only.

The management should ensure that college services are maintained and enhanced at all times. This should be emphasized to all faculty members dealing with the students in the higher level as the latter have progressing expectations with regard to college services. Meanwhile, since this study has proven that reliability and assurance 
play as predictors of satisfaction, emphasis on addressing the weak points under these dimensions should be carefully taken into consideration.

\section{References}

Al-Momani, M. M. (2015). Gap Analysis between Perceptions and Expectations of Medical-Surgical Patients in a Public Hospital in Saudi Arabia. Medical Principles and Practice, 25(1), 79-84. https://doi.org/10.1159/000441000

Alves, H., \& Raposo, M. (2010). The influence of university image on student behaviour. International Journal of Educational Management, 24(1), 73-85. https://doi.org/10.1108/09513541011013060

Bhuian, S. N. (2016). Sustainability of Western branch campuses in the Gulf Region: Students' perspectives of service quality. International Journal of Educational Development, 49, 314-323. https://doi.org/10.1016/j.jijedudev.2016.05.001

Đonlagić, S., \& Fazlić, S. (2015). Quality assessment in higher education using the SERVQUALQ model. Management: journal of contemporary management issues, 20(1), 39-57.

Dorta-Guerra, R., Marrero, I., Abdul-Jalbar, B., Trujillo-Gonzalez, R., \& Torres, N. V. (2019). A new academic performance indicator for the first term of first-year science degrees students at La Laguna University: A predictive model. FEBS open bio, 9(9), 1493-1502. https://doi.org/10.1002/2211-5463.12707

Grayson, J. P. (2004). The Relationship Between Grades and Academic Program Satisfaction Over Four Years of Study. Canadian Journal of Higher Education, 34(2), 1-34. https://doi.org/10.47678/cjhe.v34i2.183455

Grönroos, C. (1984). A Service Quality Model and Its Marketing Implications. European Journal of Marketing, 18(4). https://doi.org/10.1108/EUM0000000004784

Grubor, A., Salai, S., \& Lekovic, B. (2009). Service Quality as a Factor of Marketing Competitiveness. Romania: Association of Economic Universities.

Hamzah, Z. L., Lee, S. P., \& Moghavvemi, S. (2017). Elucidating perceived overall service quality in retail banking. International Journal of Bank Marketing. https://doi.org/10.1108/IJBM-12-2015-0204

Jain, R., Sinha, G., \& De, S. K. (2010). Service quality in higher education: An exploratory study. Asian Journal of Marketing, 4(3), 144-154. https://doi.org/10.3923/ajm.2010.144.154

Janzen, D., Fitzpatrick, K., Jensen, K., \& Suveges, L. (2013). Women in pharmacy: A preliminary study of the attitudes and beliefs of pharmacy students. Canadian pharmacists journal/Revue des pharmaciens du Canada, 146(2), 109-116. https://doi.org/10.1177/1715163513481323

Jhandir, S. U. (2012). Customer satisfaction, perceived service quality and mediating role of perceived value.

Kelso, R. S. (2008). Measuring undergraduate student perceptions of service quality in higher education. University of South Florida.

Long, D. (2018). Overcoming the cultural teaching gap: An evaluative study of urban teachers' implementation of culturally relevant instruction (Doctoral dissertation, University of Southern California).

Meštrović, D. (2017). Service quality, students' satisfaction and behavioural intentions in STEM and IC higher education institutions. Interdisciplinary Description of Complex Systems: INDECS, 15(1), 66-77. https://doi.org/10.7906/indecs.15.1.5

Nadi, A., Shojaee, J., Abedi, G., Siamian, H., Abedini, E., \& Rostami, F. (2016). Patients' Expectations and Perceptions of Service Quality in the Selected Hospitals. Medical Archives, 70(2), 135. https://doi.org/10.5455/medarh.2016.70.135-139

Oluwunmi, A. O., Emeghe, I., Oni, A. S., \& Ajayi, O. O. (2016). Demographic Factors and Students' Satisfaction in Nigerian Private Universities. Covenant Journal in Research \& Built Environment (CJRBE), 4(2), 87-98.

Onditi, E. O., \& Wechuli, T. W. (2017). Service quality and student satisfaction in higher education institutions: A review of literature. International Journal of Scientific and Research Publications, 7(7), 328-335.

Osman, A. R., \& Saputra, R. S. (2019). A pragmatic model of student satisfaction: a viewpoint of private higher education. Quality Assurance in Education, 27(2), 142-165. https://doi.org/10.1108/QAE-05-2017-0019

Parasuraman, A., Zeithaml, V., \& Berry, L. (2002). SERVQUAL: A multiple-item scale for measuring consumer perceptions of service quality. Retailing: critical concepts, 64(1), 140.

Pena, M. M., Silva, E. M. S. D., Tronchin, D. M. R., \&Melleiro, M. M. (2013). The use of the quality model of 
Parasuraman, Zeithaml and Berry in health services. Revista da Escola de Enfermagem da USP, 47(5), 1227-1232. https://doi.org/10.1590/S0080-623420130000500030

Prakash, A. V., \& Muhammed, F. S. (2016). Service Quality in Higher Education: An Antecedent to Satisfaction and Behavioral Intentions. International Journal of Management and Applied Science, 2(5), 73-79.

Qadeer, S. (2014). Service Quality \& Customer Satisfaction: A case study in Banking Sector.

Saleem, S., Moosa, K., Imam, A., \& Ahmed Khan, R. (2017). Service quality and student satisfaction: the moderating role of university culture, reputation and price in education sector of pakistan. Iranian Journal of Management Studies, 10(1), 237-258.

Selvi, M. V., \& Ponniah, V. M. (2017). Service Quality (ServQual) on Pharmaceutical Students Satisfaction of Pharmaceutical Educational Institutions in Sikkim State, India. Journal of Management (JOM), 4(2).

Shpëtim, Ç. (2012). Exploring the relationships among service quality, satisfaction, trust and store loyalty among retail customers. Journal of Competitiveness, 4(4), 16-35. https://doi.org/10.7441/joc.2012.04.02

Son, H. T., Ha, N. T., \& Khuyen, P. T. M. (2018). Measuring Students' satisfaction with higher education service-An experimental study at Thainguyen University. International Journal of Business Marketing and Management (IJBMM), 3(4), 21-34.

Sureshchandar, G. S., Rajendran, C., \& Anantharaman, R. N. (2002). The relationship between service quality and customer satisfaction-a factor specific approach. Journal of services marketing, 16(4), 363-379. https://doi.org/10.1108/08876040210433248

Van Truong, H., Pham, C. H., \& Vo, N. H. (2016). Service Quality and Students Level of Satisfaction in Private Colleges in Vietnam. International Journal of Financial Research, 7(3), 121. https://doi.org/10.5430/ijfr.v7n3p121

Varshney, D. (2019). The strides of the Saudi female workforce: Overcoming constraints and contradictions in transition. Journal of International Women's Studies, 20(2), 359-372.

Weerasinghe, I. S., \& Fernando, R. L. (2017). Students'Satisfaction in Higher Education.

Zareim, E., Daneshkohan, A., Pouragha, B., Marzban, S., \& Arab, M. (2015). An Empirical study of the Impact of Service Quality on patient Satisfaction in private Hospitals, Iran. Global journal of health science, 7(1), 1. https://doi.org/10.5539/gjhs.v7n1p1

\section{Copyrights}

Copyright for this article is retained by the author(s), with first publication rights granted to the journal.

This is an open-access article distributed under the terms and conditions of the Creative Commons Attribution license (http://creativecommons.org/licenses/by/4.0/). 